Intelektual Islam Dan Kontribusianya...

\title{
INTELEKTUAL ISLAM \\ DAN KONTRIBUSIANYA ATAS KEMAJUAN DUNIA BARAT
}

\author{
Ach Syaikhu \\ Fakultas Tarbiyah IAI Al-Falah As-sunniyyah Kencong Jember \\ Ach.syaikhu@gmail.com
}

\begin{abstract}
Islam is a religion that has virtue values, which are rahmatan lil'alamin. In the designation as a universal religion, namely the teachings of Islam which is intended for all people, not related to place and time. This assures us that Islam and its teachings are a basic key in constructing the social life of society. Historically, Islam has had a major role in the progress of the world, including in the West. This paper discusses the forms of Islamic intellectual contributions and their thoughts on the progress of civilization in the Western World. The author uses the method of literature study to discuss and dissect more deeply the contribution of Islamic intellectuals to the progress of the West. The results obtained are, Islam contributes greatly to the advancement of Western civilization, which when the Western world experiences the formation of thought in the development of science and civilization, at that time Islam also experienced a glory period. This is what makes Western scientists flock to explore Islam deeper and apply it back to the West.
\end{abstract}

Keywords: Islamic Intellectuals, Western World Civilization.

\begin{abstract}
Abstrak
Islam merupakan agama yang memiliki nilai-nilai kebajikan, yang bersifat rahmatan lil'alamin. Dalam sebutannya sebagai agama universal, yakni ajaran Islam yang diperuntukkan untuk semua orang, tidak terkait pada tempat dan waktu. Ini meyakinkan kita bahwa Islam dan ajarannya adalah sebuah kunci dasar dalam mengkontruksi kehidupan sosial masyarakat. Secara historis, Islam memiliki peran besar dalam kemajuan dunia, termasuk di Barat. Makalah ini membahas bentuk kontribusi intelektual islam beserta pemikirannya terhadap kemajuan peradaban di Dunia Barat. Penulis menggunakan metode studi literature untuk membahas dan membedah lebih dalam terkait kontribusi intelektual Islam atas kemajuan bangsa Barat. Adapun hasil yang didapatkan ialah, Islam berkontribusi besar terhadap kemajuan peradaban dunia Barat, yang mana ketika dunia Barat mengalami setaknasi pemikiran daalm perkembangan ilmu pengetahuan dan peradaban, saat itu pula Islam mengalami masa kejayaan. Hal ini yang menjadikan para Ilmuwan Barat berbondong-bondong untuk menggali Islam lebih dalam dan menerapkannya kembali ke Barat.
\end{abstract}

Keywords: Intelektual Islam, Peradaban Dunia Barat.

Falasifa, Vol. 10 Nomor 2 September 2019 | 91 


\section{Ach Syaikhu}

\section{PENDAHULUAN}

Setelah runtuhnya dinasti Abbasiyah di Bakdad dan dinasti Umayyah di Spanyol, kemajuan dan kejayaan Islam mengalami kemunduran diberbagai aspek bidang kehidupan baik secara politik, kebudayaan, peradaban, pemikiran dan dlm bidang keamanan. Kondisi seperti ini terus berjalan sampai sekarang sehingga dunia Islam selalu kalah bertarung dalam berebut berbagai persoalan dunia baik dunia politik, budaya, teknologi dan ilmu pengetahuan.

Sementara saat ini dunia barat terus berkembang dan telah mencapai kemajuan yang pesat dari berbagai bidang terutama pengetahuan teknologi, peradaban dan keamanan. Barat dianggap mampu menyajikan berbagai temuan baru secara dinamis dan variatif. Sehingga dapat memberikan kontribusi positif yang besar terhadap science dan teknologi modern saat ini. Walau demikian kemajuan barat yang diperoleh tidak bisa dilepaskan oleh kemajuan Islam saat itu ada korelasi antara kemajuan dan kejayaan Islam terhadap perkembangan pemikiran ilmu pengetahuan dan teknologi di dunia Eropa saat ini. Dalam catatan sejarah telah menunjukkan fakta kongkrit bawa kemajuan yang mereka peroleh tidak bisa dipisahkan dengan perkembangan intelektual yang begitu pesat pada masa sebelumnya, yakni masa kejayaan dunia Islam. Saat itu, dunia barat mengalami masa kegelapan yang dikarenakan doktrin-doktrin gereja yang banyak bertentangan dengan dunia ilmu pengetahuan, disisi lain di belahan dunia timur, umat Islam telah membentuk suatu peradaban gemilang yang dilatarbelakangi oleh semangat ilmiah yang berkembang dengan pesat. Adapun kemajuan saat itu yang diperoleh umat Islam dirasakan juga oleh masyarakat non muslim termasuk orang orang Eropa. Seiring dengan kemunduran yang dialami oleh umat Islam di abad pertengahan, kalaborasi dunia Islam dan barat berikutnya menjadi transformasi intlektual dunia Islam dan dunia barat proses hubungan ini melahirkan gerakan renaisance, reformasi, rasionalisme, dan aufklarung di dunia Barat. Dari sini dapat dikatakan kemajuan science dan teknologi dan semangat intlektualme yang berkembang cepat di dunia barat saat itu, tidak terlepas dari kontribusi kemajuan umat Islam pada masa sebelumnya. Untuk lebih bisa dipahami artikel ini akan mencoba mendiskripsikan proses terjadinya Intelektual Islam dan kontribusinya atas kejuan dunia barat dalam perspektif lintasan sejarah. 
Intelektual Islam Dan Kontribusianya...

\section{PEMBAHASAN}

I. Pembahasan.

A. Masa Kejayaan Islam dan Kegelapan Dunia Barat.

Disaat dunia barat mengalami staknasi dalam dunia pemikiran untuk pengembangan keilmuan dan peradaban manusia. Islam telah mencapai kejayaan dalam perkembangan pemikiran ilmu pengetahuan sehingga perdapanya sangat tinggi. Hal ini terjadi karena terdorong dua faktor yaitu internal dan ekternal. Dari faktor internal, ajaran Islam sangat mendorong umatnya untuk mengembangkan ilmu pengetahuan. Dimana wahyu yang pertama turun kepada nabi Muhammad adalah perintah Iqra' yang menunjukkan bahwa ajaran Islam memberikan perhatian yang sangat besar terhadap pengembangan ilmu pengetahuan. Sementara dorongan dari segi ekternal diperoleh melalui kekuatan sistem pendidikan yang imtegral dan dinamis, diantaranya ketersediaan perpustakaan yang memadai pada setiap lembaga pendidikan. ${ }^{1}$ Serta dorongan dari penguasa dengan menyediakan sarana yang dibutuhkan para ilmuawan dalam mengembangkan teori-teorinya bahkan menghargai setiap temuan para ilmuwan tersebut dengan harga yang sangat tinggi. ${ }^{2}$ Sehingga ekspansi yang dilakukan oleh umat Islam telah sampai ke luar jalur jazirah Arab, hingga ke Eropa (barat) yang menyebabkan umat Islam bersentuhan dengan ilmu pengetahuan warisan Yunani, Romawi, dan Persia kuno. Upaya dinamis tersebut bukan saja dilakukan para ilmuwan secara an sih, akan tetapi juga akibat campur tangan penguasa waktu itu yang secara intens menaruh perhatian yang sangat besar terhadap karya-karya klasik tersebut. Diantara penguasa yang menaruh perhatian demikian tinggi terhadap perkembangan ilmu pengetahuan tersebut adalah Nizam al-Mulk. Untuk merealisasikan keinginan tersebut, ia mengambil kebijaksanaan diluar kebiasaan penguasa sebelumnya, yaitu mendirikan lembaga pendidikan Universitas Nizhamiyah yang semua biaya oprasionalnya menjadi tanggung jawab penguasa. ${ }^{3}$

\footnotetext{
${ }^{1}$ Samsul Nizar, Sejarah dan Pergolakan Pemikiran Pendidikan Islam: Potret Timur Tengah Era Awal dan Indonesia, (Jakarta: Quantum Teaching, 2005), hlm 27

${ }^{2}$ Ibid., hal. 31

${ }^{3}$ Ibid., hIm.25
}

Falasifa, Vol. 10 Nomor 2 September 2019 | 93 


\section{Ach Syaikhu}

Tumbuhnya lembaga pendidikan yang demikian ini bukan hanya diwilayah kekuasaan Nizam al-Mulk saja, akan tetapi juga diwilayah wilayah Islam lainya. Seperti Universitas Muatansariyah, Cordova, Granada, Teledo, dan daerah lainya. ${ }^{4}$ Pada masa ini juga tumbuh sejumlah tokoh dan ilmuwan dengan gemiling yang menumbuhkan budaya

ilmiah. Ilmuwan - ilmuwan yang muncul saat itu tidak mengenal dikotomi, banyak diantara mereka yang bergelut dan konsen dalam dunia keilmuan sekaligus sebagai ulama. Mereka tersebar diberbagai daerah dibawah kekuasaan "Daulah Islamiyah" yang ada waktu itu yaitu : Dinasti Uamayyah timur dan barat, Abbasiyah di Bagdad, Fatimiyah di Mesir, dan masih banyak lagi yang lainya. Diantara tokoh tokoh ilmuwan yang muncul ialah Ibnu Sina, selain seorang dokter, ia juga dikenal sebagai filusuf muslim yang terkenal dan ahli tasawuf. Di usia 18 tahun, ia telah menguasai segala ilmu pengetahuan yang meliputi al-Qur'an dan tafsirnya, linguistik, sastra, kedokteran, dan pendidikan. ${ }^{5}$

Pada akhir abad ke-12 masehi muncul seorang pengikut Aristoteles yang tersebar dalam kalangan filsafat Islam, dia adalah Abu al-Walid Muhammad Ibnu Ahmad ibnu Muhammad Ruyd dilahirkan di Cordova, Andalus pada tahun 510 H/1126 M. ${ }^{6}$

Dalam segi ilmu pengetahuan, doktrin gereja di dunia barat cenderung menolak kajian ilmu pengetahuan dan budaya berfikir atau filsafat yang pernah berkembang pada masa sebelumnya di Yunani. Hal ini telah digambarkan oleh Abdul Azis Dahlan:

"Bapak-bapak gereja Kristen, setelah agama Kristen menjadi agama resmi Imperium Romawi pada dasawarsa ketiga abad keempat masehi, bersemangat melakukan kampanye membasmi ilmu dan filsafat. Mereka menganggap ilmu sebagai sihir... kebencian mereka pada pengetahuan manusia dinyatakan dengan peribahasa mereka "ketidaktahuan adalah sumber kesalehan". Perpustakaan-perpustakaan di Kota Alexandria, atas anjuran bapak-bapak

${ }^{4}$ Ibid., hlm 26-27

${ }^{5}$ Ramayulis dan Samsul Nizar, Ensiklopedi Tokoh Pendidikan Islam: Mengenal Tokoh Pendidikan Islam di Dunia Islam dan Indonesia, (Jakarta:Quantum Teaching, 2005), hlm.30.

${ }^{6}$ Sirajutdin Zar, Filsafat Islam Filosoh dan Filsafatnya, (Jakarta: PT Raja Grafindo Persada, 200, hlm, 221.

Falasifa, Vol. 10 Nomor 2 September 2019 | 94 
Intelektual Islam Dan Kontribusianya...

gereja, dibumihanguskan pada tahun 389 M. Sekolah-sekolah filsafat di Athena ditup pada tahun $29 \mathrm{M}$, dan para pengajarnya diusir. Perpustakaan istana yang didirikan oleh Kaisar Agusnius Cesar, dibakar oleh Paus Gregorius Agung (590-604 M), ia melarang orang membaca karya para pengarang Yunani dan Romawi kuno. ${ }^{7}$

Sikap demikian diambil demi kepentingan pribadi dan penguasa pada saat itu. Atas dasar ketidaktahuan umat inilah, sehinga diharapkan ketidak munculan sebuah perlawanan terhadap kezaliman yang mereka lakukan. Hal ini senada seperti ditulis Abul Hasan Ali Nadwi dalam karyanya Islam and the Word, bahwa:

Para wali gereja dilanda pelanggaran moral yang mencolok. St. Jerome sendiri mengeluh bahwa perjamuan banyak uskup, diliputi kemewahan ala gubernur provinsi. Jabatan-jabatan gereja diperoleh dengan tipu daya, kemurahan hati, kelonggaran, izin-izin, pengampunan, pengikutsertaan, dan hak-hak istimewa diperjualbelikan seperti barang dagangan. Paus Innocent VIII menggadaikan mahkota paus. Tentang Leo I dikatakan bahwa ia telah memboroskan tabungan-tabungan para pendahulunya. ${ }^{8}$

Di masa tersebut, para ilmuwan dianggap kafir, zindik, dan keluar dari agama Masehi. Oleh sebab itu, mereka disiksa dan dihukum dengan bermacammacam hukuman. Sebagian melarikan diri ke Asia kemudan menetap di Syiria, irak, dan Jazirah Arabia. Disana mereka dengan bebas mengajarkan ilmu dan filsafat Yunani. Oleh karena tindakan gereja yang demikian, maka dunia barat menjadi senyap dari filsafat dan ilmu pengetahuan, selain dari ilmu agama Masehi.

Doktrin-doktrin gereja terus berkembang hingga abad pertengahan, dan sampai pada saat itulah dunia barat mengalami kegelapan. Keadaan ini berakhir ketika adanya perlawanan para ilmuwan yang mempertahankan pendirian ilmiahnya dan berkoalisi dengan raja untuk menumbuhkan kekuasaan gereja. Mohammed Arkoun (200) menjelaskan bahwa koalisi ini berhasil dan tumbanglah kekuasaan

\footnotetext{
7 Abdul Azis Dahan, Agama dan Filsafat, dalam Jurnal Al-Ta'lim, edisi XI September-Desember 2000, (Padang; IAIN IB) Press), hlm, 4-5

${ }^{8}$ Abdul Hasan Ali Nadwi, Islam and the Word, Penj. Adang Affandi, (Bandung:Angkasa, 1987), hlm 1444
}

Falasifa, Vol. 10 Nomor 2 September 2019 | 95 


\section{Ach Syaikhu}

gereja sehingga muncul reneissance yang pada akhirnya melahirkan sekularisasi dan lahirlah dikotomi antara ilmu dan gereja (agama). ${ }^{9}$

\section{B. Kontribusi Keilmuan Islam dalam Perkembangan Dunia Barat Modern}

Dalam sejarahnya, mulai abad kesebelas hingga abad ketigabelas, khususnya pada tahun 1050-1300 M, umat Islam telah mencapai zaman keemasan, ditandai dengan adanya kebangkitan dinamika intelektualitasnya dalam segala bidang ilmu pengetahuan secara integral dan harmonis. Sebaliknya, terdapat stagnasi ilmu pengetahuan di belahan Eropa dikarenakan dogma gerejani. Banyak lembaga pendidikan yang mengajarkan ilmu dan filsafat yunani ditutup.

Kondisi demikian yang menyebabkan para ilmuwan Eropa yang keluar dari negaranya. Mereka kagum terhadap Islam, dengan kebijaksanaan pemerintah dan semangat umat dalam pengembangan ilmu pengetahuan menjadi sebuah daya tarik tersendiri bagi mereka untuk terus mencari tahu dan menggali khazanah keilmuwan dunia Islam. Manuskrip Yunani yang telah "diselamatkan” dan ditambal oleh Islam mereka pelajari. Inilah yang menyetimulus para orientalis untuk menanamkan ide pencerahan dan kebakitan Eropa dari masa suramnya. Adapun paya-upaya untuk mentransferkan ilmu pengetahuan yang berkembang di dunia Islam ke dunia Eropa melalui, menterjemahkan sejumlah buku-buku, juga dengan mengirimkan sejumlah mahasiswa mereka untuk belajar di dunia Islam. Hasil dari pencerahan ilmu pengetahuan inilah yang akhirnya memunculkan institusi baru ilmu pengetahuan di Eropa. Dari sini, kemudian lahir beberapa lembaga pendidikan di Eropa, seperti Universitas Salermo, dan Bologna di Italia.

Demikian upaya-upaya yang dilakukan oleh para ilmuwan Eropa dalam mentransfer ilmu pengetahuan di dunia Islam pada abad pertengahan, khusunya di Spanyol yang secara letak geografis lebih dekat dengan negara-negara non-muslim di Eropa. Dari sini, muncul suatu pembaharuan pemikiran para ilmuwan Eropa sehingga melahirkan reaksi terhadap kebijaksanaan gerejani secara nyata. Konsekuensi dari upaya ini akhirnya membuahkan apa yang disebut renaissance.

\footnotetext{
${ }^{9}$ Mohammed Arkoun, Rethinking Islam, Penj. Yudian W. Asmin dan Latiful Khuluq, (Yogyakarta: Pustaka Pelajar; 1996), hlm. 24.
}

Falasifa, Vol. 10 Nomor 2 September 2019 | 96 
Intelektual Islam Dan Kontribusianya...

Dalam perkembangan ilmu pengetahuan, para ilmuwan muslim telah melahirkan berbagai karya besar yang kemudian menjadi referensi bagi para ilmuwan Barat. Adapun beberapa karya tersebut dalam bidang pendidikan, antara lain: Ghabus Namah (kumpulan nasihat moral dan pendidikan) oleh Amir Kaiwakus Ibn Iskandar Ibn Ghabus'i Washmgir Ibn Ziar, dan Siyasat Namah (tentang etika) oleh Nizam Al-Mulk, dan sebagainya. Kendati demikian, intelektual Islam tidak hanya berkontribusi pada bidan pendidikan saja, tetapi juga pada bidang Astronomi, Matematika, Fisika, Kimia, Ilmu Hayat, kedokteran, Filsafat, Sastra, Geografi, dan Sejarah, Sosiologi dan Ilmu Politik, Arsitektur dan Seni Rupa, dan Musik. Berikut adalah penjelasan kontribusi intelektual Islam atas dunia Barat:

a. Bidang Astronomi, dalam literatur Islam disebut ilmu falak. Para ilmuwan muslim sangat tertarik dengan bidang ilmu ini disamping bidan ilmu matematika, karena peribadatan Islam didukung oleh kedua bidang tersebut. Seperti halnya dalam penentuan awal dan akhir bulan Ramadhan, Hari Raya Idul Adha, dsb. Oleh sebab itu, perlu perhitungan yang cermat berdasarkan pada perputaran benda-benda langit. Adapun para ahli Astronom muslim yang tersohor adalah Al Batani, yang masuk dalam 20 besar ahli astronomi terpenting dunia.

b. Bidang Matematika, dalam literatur Islam disebut aljabar (perhitungan), sedangkan istilah algoritme berasal dari nama penemunya, yakni Al-Khawarizmi, yang memiliki nama lengkap Muhammad bin Musa bin Khawarizmi. Adapun buku yang ia tulis berjudul Al-Jbr Wa'10Maakalala (Perhitungan dan Simbol.

c. Bidang Fisika, ilmu ini berkaitan erat dengan ilmu astronomi. Sehingga karya-karya tentang optik seperti seperti yang ditulis Hassan Ibn Haitam (96-1039 M) juga merupakan dasar bangunan ilmu fisika, yakni dasar bagi pengadaan teropong dan fotografi. Di samping itu, penelitiannya mengenai kaca pembesar telah memberi inspirasi kepada Bacon dan Kepler yang menemukan teleskop maupun mikroskop. ${ }^{10}$

d. Bidang Kimia. Dalam perkembangannya, orang arablah yang berkontribusi besar dalam penemuan sejumlah zat kimia seperti alkohol, asam sulfur, maupun asam nitrat. Bersamaan dengan itu, ditemukan juga potasium, asam moniak, nitrat perak, sublimat korosif, dan preparasi merkuri. Adapun ilmuan muslim pada bidang kimia,

${ }^{10}$ Ibid., hlm. 204

Falasifa, Vol. 10 Nomor 2 September 2019 | 97 


\section{Ach Syaikhu}

antara lain; Abu Musa Jakfar Al-Kufi (Djeber) yang hidup pada paruh kedua abad VIII dan telah menulis semacam ensiklopedi dan rangkuman ilmu kimia.

e. Ilmu hayat, dalam bidang ini, bangsa Arab melekukan kajian dan observasi secara intensif sehingga mereka berhasil memperkaya daftar tetumbuhan yang tercantum dalam 'Daftar Dioscorides' yang berisi sekitar 2000 spesies.

f. Kedokteran. Adapun seorang ahli kedokteran muslim yang terkenal di dunia barat adalah Abu Ali Al-Hussein Ibn Abdallah Ibn Sina, atau yang dikenal dengan panggilan Ibn Sina atau Avicenna. Kemudian Ibn Al-Nafis dari Siria yang pada tahun 1289 berhasil mempertontonkan sistem sirkulasi darah secara akurat, 300 tahun sebelum Servet, seorang dokter berkebangsaan Portugis yag selama ini dianggap sebagai penemu pertama. ${ }^{11}$

g. Filsafat. Selain ahli dalam bidang kedokteran, Ibn Sina atau Avicenna juga merupakan seorang ahli filsafat. Beliau telah membentuk sistem keilmuwan dan pandangan filsafat skolatiknya secara jelas. Adapun karya-karya utamanya adalah Kitab Al-Shifa (Buku tentang kesehatan), Al-Hidayat Fi'il Hikinat (Petunjuk ke arah kebijaksanaan) dan Kitab Al-Isharat Wa'l Tanbihat (Pegangan bagi pengajaran dan Peringatan).

h. Sastra, adapun kontribusi ilmuwan muslim terbukti dengan hasil kajian Asin Palacios atas karya-karya surealis dalam Islam dan atas buku La Devina Comedia karya Dante Aleghery yang menyimpulkan bahwa Dante telah mendapat pengaruh yang besar dari karya mistik Muhyidin Ibn arabi maupun penyair buta Abul Ala AlMaari.

i. Geografi dan Sejarah. Orang Arab menekuni bidan ilmu ini, dalam bukunya yang berbahasa Inggris berjudul Golden Pastures, Hasan Ali Al Masudi memaparkan gambaran lengkap setiap negri yang pernah dikunjunginya pada pertengahan abad X. Bahkan, sejarah menunjukkan bahwa selama lebih dari 3 abad para ahli kartografi Eropa senantiasa mengutip karya-karya geografi muslim, seperti karya Nasrudin Tusi maupun hasil observasi Al-Koshaji yang telah berhasil menyusun hasil petualangannya di Cina dan mengoreksi perhitungan garis lintang bumi maupun ukuran bumi.

${ }^{11}$ Ibid., hlm. 206-207

Falasifa, Vol. 10 Nomor 2 September 2019| 98 
Intelektual Islam Dan Kontribusianya...

j. Sosiologi dan Ilmu Politik. Ibn Khaldun (1332-1406 M) merupakan seorang pemikir filsafat sosiologi dan sejarah yang terkenal dalam peradaban Barat. Salah satu buku yang terkenal adalah Prolegomena membahas refleksi umum sejarah manusia dan berbagai macam peradaban manusia sebagai hasil dari perbedaan iklim, kehidupan kaum pengembara maupun yang telah menetap, dan adat istiadat serta latar belakang peradaban yang berbeda, termasuk kelembagaan sosial, ilmu pengetahuan dan seni yang mereka kembangkan.

k. Arsitektur dan Seni Rupa. Pada bidang ini, ditampakkan hasil arsitektur muslim berupa istana ataupun masjid yang bergelapan, yang kemudian hari berpengaruh pada seni bangunan gereja pada abad pertengahan di Eropa. Sementara itu, seni rupa muslim berupa hiasan kaligrafi bertuliskan Arab juga tampak dalam banguna gereja, seperti pada sebuah pintu katredal du Puy yang dilingkari kaligrafi yang berbunyi Ma Sha Allah (Itulah kehendak Allah)

1. Musik. Seorang Musikus muslim bernama Abul Hasan Ali Ibn Nafis atau sering disebut Ziriyab, telah mendirikan konservatorium musik-musik Andalusia. Sejak itu teori musik mulai dikembangkan oleh Al-Faribi, yang menulis Kitab Al-Musiki (Pegangan Musik), dan dengan menggunakan prinsip-prinsip ilmu matematika dan ilmu fisika para penulis musik mampu memberi penjelasan secara ilmiah tentang suara dan bagaimana mendorong pembuatan instrumen musik.

m. Memperkaya kurikulum pendidikan barat dengan adanya proses penerjemahan karya-karya umat islam di berbagai bidang ilmu.

n. Orang Islam telah memeperkenalkan tentang metode eksperimental yang merupakan perkembangan yang menetukan terhadap spekulasi yang membingungkan bagi orang-orang Yunani sebelumnya.

o. Telah diperkenalkannya sistem notasi dan desimal oleh para ilmuwan muslim ke dunia barat.

p. Umat islam telah memperlihatkan sikap inklusifitasnya terhadap kebudayaan lokal.

q. Umat islam telah memberikan model lembaga pendidikan, baik pendidikan rendah dan terutama pendidikan tinggi kepada orang-orang barat. Padahal model yang demikian selama ini belum ada dalam kebudayaan umat manusia. 


\section{Ach Syaikhu}

r. Umat islam telah memberikan modal berupa rumah sakit, sanitasi, serta makanan yang sehat dan bergizi kepada barat.

s. Umat islam telah melahirkan gerakan-gerakan yang sangat berpengaruh terhadap kemajuan dunia barata, antara lain; kebangkitan kembali (Renaissance), gerakan pembaharuan agama Kristen, Rasionalisme, Pencerahan (Aufklarung, englithment)

t. Umat islam telah memperkenalkan pabrik-pabrik kertas ke dunia barat untuk menulis karya-karya ilmiah

Disamping itu, masih banyak kontribusi berharga yang lain dari intelektual islam terhadap kemajuan dunia Barat. Sehingga, dapat disimpulkan bahwa setelah mendapat pencerahan oleh peradaban Islam, mereka pun mengembangkan ilmu pengetahuan yang lebih canggih pada abad sesudahnya, terutama di bidan ilmu pengetahuan dan teknologi. Hal ini membuktikan bahwa, intelektual islam telah memberikan sumbangsih yang besar terhadap kemajuan dunia barat pada masa kejayaan umat Islam.

\section{PENUTUP}

Disaat dunia Barat mengalami setaknasi pemikiran dalm perkembangan ilmu pengetahuan dan peradaban, saat itu pula Islam mengalami masa kejayaan yang dimulai abad ke sebelas sampai pada abad ke tigabelas pada masa kerajaan dinasti Mu'awiyah di Sepanyol dan kejaan dinasti Abbasiyah Bagdad.

Faktor yang mengakibatkan kemunduran secara drastis sampai terjadi masa kegelapan dunia Barat adalah karena adanya dokma geraja yang di kawal penguasa saat itu, bertentangan dengan perkembangan ilmu pengetahuan sehingga banyak lembaga pendidikan yang mengajarkan ilmu dan filsafat Yunani di tutup.

Kondisi yang demikian ini membuat membuat ilmuwan barat keluar dari negrinya dan mendatangi negri Islam untuk menggali khazanah keilmuan yang berkembang saat itukhususnya di Spanyol dari berbagai perkembangan disiplin ilmu pengetahuan yang ada pada saat itu diantaranya bidang ilmu Astronomi, matematika, fisika, kimia, kedokteran, seni, arsitektur, filsafat dll. 
Intelektual Islam Dan Kontribusianya...

\section{DAFTAR PUSTAKA}

Nizar, Samsul . 2005 . Sejarah dan Pergolakan Pemikiran Pendidikan Islam: Potret Timur Tengah Era Awal dan Indonesia. Jakarta: Quantum Teaching

Ramayuli , Nizar Samsul. 2005 .Ensiklopedi Tokoh Pendidikan Islam: Mengenal Tokoh Pendidikan Islam di Dunia Islam dan Indonesia, Jakarta: Quantum Teaching

Zar, Sirajutdin. 2005. Filsafat Islam Filosoh dan Filsafatnya. Jakarta: PT Raja Grafindo Persada

Dahan, Abdul Azis. 2000. Agama dan Filsafat, dalam Jurnal Al-Ta'lim, edisi XI September Padang; IAIN IB PRESS

Ali Nadwi, Abdul Hasan.1987. Islam and the Word. Bandung: Angkasa

Arkoun, Mohammed. 1996. Rethinking Islam. Yogyakarta: Pustaka Pelajar 